\title{
DESENVOLVIMENTO DE UMA TÉCNICA IMUNOENZIMÁTICA (ELISA) SIMPLES E RÁPIDA PARA A PESQUISA DE ANTICORPOS IgG ANTI-DNA NATIVO NO LÚPUS ERITEMATOSO SISTÊMICO
}

\author{
Bruna A. Brajeiro, Lisandra A. Suzuki, Elisângela O. R. Cavalcante, Cláudio L. Rossi.
}

\section{Resumo}

O lúpus eritematoso sistêmico (LES) é uma doença autoimune crônica, que se caracteriza pela produção de autoanticorpos direcionados a um grupo amplo e heterogêneo de componentes do próprio indivíduo, podendo afetar diversos órgãos, resultando em várias manifestações clínicas e anormalidades laboratoriais.O diagnóstico do LES é baseado em observações clínicas e testes laboratoriais. O presente estudo teve como objetivo desenvolver uma técnica ELISA simples e rápida para a pesquisa de anticorpos IgG anti-DNA nativo (DNAn). A técnica ELISA para a pesquisa de anticorpos anti-DNAn apresentou ótimos resultados em termos de sensibilidade $(93,7 \%)$ e especificidade $(97,9 \%)$, podendo ser de grande utilidade tanto na pesquisa como na rotina diagnóstica.

\section{Palavras-chave:}

Lupús Eritematoso Sistêmico, ELISA, anticorpo anti-DNA.

\section{Introdução}

O lúpus eritematoso sistêmico (LES) é uma doença autoimune crônica, que se caracteriza pela produção de autoanticorpos direcionados a um grupo amplo e heterogêneo de componentes do próprio indivíduo, podendo afetar diversos órgãos, resultando em várias manifestações clínicas e anormalidades laboratoriais. A etiologia do LES não é completamente conhecida, porém acredita-se que a interação de fatores genéticos, ambientais e hormonais estejam envolvidos no desenvolvimento da doença.

O diagnóstico do LES é baseado em observações clínicas e testes laboratoriais, incluindo a pesquisa de anticorpos anti-DNA nativo (ou de dupla hélice, DNAn), utilizando imunofluorescência indireta (Crithidia luciliae como substrato) e técnicas imunoenzimáticas (ELISA). O presente estudo teve como objetivo desenvolver uma técnica ELISA simples e rápida para a pesquisa de anticorpos $\lg G$ anti-DNAds.

\section{Resultados e Discussão}

Para o desenvolvimento da técnica ELISA foram utilizadas 32 amostras de soros de pacientes com LES, 24 amostras de soros de pacientes com artrite reumatoide e 23 amostras de soros de pessoas sadias.

Resumidamente, cavidades de placas de poliestireno (Maxisorp, Thermo Scientific Nunc, EUA) foram tratadas com uma solução de poli-L-lisina. Após incubação por $1 \mathrm{~h}$ à temperatura ambiente (TA) e $12 \mathrm{~h}$ a $4^{\circ} \mathrm{C}$ e três lavagens com solução salina tamponada com fosfatos $0,15 \mathrm{M}, \mathrm{pH}=7,3$ (SST), foram adicionados às cavidades das placas $100 \mu \mathrm{l}$ de uma solução de DNAn de timo de vitelo a $20 \mu \mathrm{g} / \mathrm{mL}$ em SST. Após incubação por $2 \mathrm{~h}$ à TA, as cavidades das placas foram lavadas três vezes com SST contendo Tween 20 e soro albumina bovina (SST-T-SAB). Em seguida, foram adicionados às cavidades das placas as amostras de soros diluídas a 1:200 em SST-T-SAB, em triplicata. Após incubação por 20 min., seguida por três lavagens com SST-T, foram adicionados às cavidades das placas $100 \mu \mathrm{l}$ do conjugado (anticorpos anti-lgG humana marcados com peroxidase) diluído em SST. Após incubação por 20 min., seguida por três lavagens com SST-T, foram adicionados às cavidades das placas $100 \mu \mathrm{l}$ do sistema substrato (tetrametilbenzidina/ $\mathrm{H}_{2} \mathrm{O}_{2}$ ). Após incubação por 5 min.,no escuro, as reações foram bloqueadas pela adição de $50 \mu \mathrm{l}$ de uma solução de ácido sulfúrico $\left(\mathrm{H}_{2} \mathrm{SO}_{4}\right)$ a $2 \mathrm{~N}$ em cada cavidade da placa. A leitura das absorbâncias das reações foi realizada a 450,630 nm em leitora de ELISA Multiskan (Labsystems, Helsinki, Finlândia) e a média das triplicatas considerada como resultado final. Utilizando o valor de cut-off determinado pelo índice J (Youden, 1950), a técnica ELISA apresentou sensibilidade de $93,7 \%$ e especificidade de $97,9 \%$.

\section{Conclusões}

A técnica ELISA para a pesquisa de anticorpos anti-DNAn apresentou ótimos resultados em termos de sensibilidade e especificidade, podendo ser de grande utilidade tanto na pesquisa como na rotina diagnóstica.

§ Fortuna G, Brennan MT. Systemic lupus erythematosus: epidemiology, pathophysiology, manifestations and management. Dent Clin North Am 2013; $57: 631-55$.

§ Pavlovic M, Kats A, Cavallo M, Chen R, Hartmann JX, Shoenfeld Y. Pathogenic and epiphenomenal anti-DNA antibodies in SLE. Autoimmune Dis 2010; 2010:1-19.

§ Sato, EL. Lúpus eritematoso sistêmico. In: Júlio C. Voltarelli. (Org.). Imunologia Clínica na Prática Médica. São Paulo: Atheneu, 2008, v.p.651-62.

$\S$ Youden,WJ. Index for rating diagnostic tests. Cancer. 1950; 3: 32-5. 